\title{
Impact of Gender on Psychological Well-Being among Post-Graduate Students
}

\author{
Kantariya Ashok S* \\ Department of Psychology, Saurashtra University, India
}

Submission: December 15, 2016; Published: January 20, 2017

*Corresponding author: Kantariya Ashok S, M.Phil. Student, Department of Psychology, Saurashtra University, Rajkot-5, Gujarat, Email: ashokkantariya1991@gmail.com

\begin{abstract}
The aim of the present study was to investigate the gender differences on psychological well-being among male and female post-graduate students. The random sampling method was used in this study. The total sample consisted of 60 post-graduate students. 30 males and 30 females studying in M.A. (Master of Arts) were selected from the various departments of Saurashtra University, Rajkot. Psychological Well-being Scale developed by Bhogle and Prakash was used to measure the psychological well-being. The result showed that there is no significant gender difference on psychological well-being among male and female post-graduate students.
\end{abstract}

Keywords: Psychological Well-Being; Post-graduate Students; Gender

\section{Introduction}

According to Huppert [1], "Psychological well-being is about lives going well. It is the combination of feeling good and functioning effectively." An individual with high psychological well-being is happy, capable, well-supported, satisfied with professional and personal life. Psychological well-being indicates physical and mental wellness. Singh [2] has stated that psychological well-being is difficult to define. It has been taken to consist of discomfort or desirability and from any disturbance of mental functions. It is a somewhat malleable concept which has to do with people's feelings about everyday life activities. Such feelings may range from negative mental states or psychological strains such as anxiety, depression, frustration, emotional exhaustion, unhappiness, dissatisfaction to a state which has been identified as positive mental health $[3,4]$.

Gender differences in psychological well-being are important because of the many efforts being made in contemporary society to empower all individuals to achieve self-actualization and utilize their full potential. In a post feminist context this incorporates the idea of an "equal opportunities" society; yet social stereotypes still remain [5]. All people are equal but not identical, and the possible differences between people need to be considered in order to empower all individuals to achieve self-actualization and to fulfill their potential (thereby promoting optimal psychological well-being), Whilst being offered equal opportunities. Current studies on the existence of gender differences, including those related to psychological well-being reflect contradictory results and a distinct lack of consensus [6]. Based on their own literature studies and qualitative experiences, Crose et al. [7] believe that gender differences do exist in almost every aspect of health and health care. In a Taiwanese study, Lu [8] discovered gender differences while examining conjugal congruence on role experiences and subjective well-being, Whilst Stephens et al. [9] found gender differences in a study examining mental health in the Canadian population. Ek [10] found no marked gender differences in a Finnish study on coping flexibility.

Objectives: To compare gender differences on psychological well-being among male and female post-graduate students.

Hypothesis: There is no significant gender difference on psychological well-being among male and female post-graduate students.

\section{Methodology}

\section{Sample}

The sample consisted of 60 post-graduate students out of which 30 were male and 30 were female students studying 
Master of Arts in various departments of Saurashtra University, Rajkot. The sample was selected by random method.

\section{Instruments}

The following Instruments were used in the present study:

Personal Data Sheet: A personal data sheet developed by the investigator was used to collect information about sex and educational status.

Psychological Well-being Scale: Gujarati version of Psychological Well-being Questionnaire developed by Bhogle and Prakash (1995) was used to measure psychological wellbeing. The questionnaire contains 26 items with true and false response alternative. It covers 10 dimensions of psychological well-being. High score indicates high level of psychological wellbeing. The test-retest reliability coefficient is 0.72 and internal coefficient is 0.84 . The author has reported satisfactory validity of the questionnaire.

\section{Procedure}

The testing was done on a group of post-graduate male and female students. The whole procedure was explained to them clearly. Obtained data were analyzed using t-test for comparing post-graduate male and female students.

\section{Result and Discussion}

The main objective of present study was to compare gender differences on psychological well-being among male and female post-graduate students. The t-test was used to find out whether gender has an impact on psychological well-being significant differences were not found between gender and psychological well-being $(t=0.99, p<0.05)$.Hence, from the statistical analysis it can be inferred that gender had no effect on psychological wellbeing. This result is similar to the study by Creed and Watson [11], and Geeta Sharma (2014), but contradictory to the studies by Mills et at. [12], Perez [13], and Roothman [14] (Table 1).

Table 1: t-test between Gender and Psychological Well-being $p<0.05$.

\begin{tabular}{|c|c|c|c|c|}
\hline Variable & $\mathrm{N}$ & Mean & $\mathrm{SD}$ & $\mathrm{t}$ \\
\hline $\begin{array}{c}\text { Post- } \\
\text { graduate } \\
\text { Males }\end{array}$ & 30 & 34.57 & 2.91 & \\
\hline 0.99 & 30 & 32.73 & 9.76 & \\
\hline $\begin{array}{c}\text { Post- } \\
\text { graduate } \\
\text { Females }\end{array}$ & 30 & & \\
\hline
\end{tabular}

The statistical analysis indicated that there was no significant impact of gender on psychological well-being. In a country like India, where gender-basis is still prevalent, the results are slightly surprising. There maybe two reasons for this, one that gender bias exists only in the society but does not affect the well-being of an individual. Another reason may be that families accept children whole-heartedly whether male or female and raise them without any bias. Females are given the same amount of rights and opportunities that males are enjoying. In fact, both the public and private sectors have sponsored various scholarships for girl students. The societal views towards Women Education and Empowerment have changed substantially over the past few decades, thus indicating the possible causes for gender to have no effect on psychological well-being.

\section{Research Implications}

The findings clearly indicate that gender has no impact on psychological well-being among male and female post-graduate students in Rajkot. This is an indication that gender bias is slowly decreasing and that children are probably raised without any differentiation.

\section{Conclusion}

There is no significant difference on psychological wellbeing among male and female post-graduate students.

\section{References}

1. Huppert FA (2009) Psychological Well-being: Evidence regarding its causes and consequences. Applied Psychology: Health and Well-being 1(2): $137-164$.

2. Singh D (1990) Concepts of Psychological Well-being: Western and Indian Perspectives. NIMHANS Journal 8: 1-11.

3. Jahoda M (1958) Current concept of positive mental health. New York: Basic Books.

4. Warr P (1978) A study of psychological well-being. Br J Psychol 69(1): 111-121.

5. Connors JV (1990) Gender differences in perceived advancement problems, stress and satisfaction of university. Unpublished doctoral thesis, University of Missouri.

6. Carol D Ryff, Burton Singer (1998) The contours of positive human health. Psychological Inquiry 9(1): 1-28.

7. Royda Crose, Donald R Nicholas, David C Gobble, Beth Frank (1992) Gender and Wellness: A multidimensional systems model for counseling. Journal of Counseling \& Development 71(2): 149-156.

8. Lu L (2000) Gender and conjugal differences in happiness. J Soc Psychol 140(1): 132-141.

9. Stephens T, Dulberg C, Joubert N (1999) Mental health of the Canadian population: a comprehensive analysis. Chronic Dis Can 20(3): 118-126.

10. Ek E (2000) Assessment of coping flexibility of young adults in a population based study-The Flax-Method Revised Oulu Regional Institute of Occupational Health. Finland. Seminar 6.

11. Peter A Creed, Tania Watson (2003) Age, Gender, Psychological Wellbeing and the Impact of Losing the Latent and Manifest Benefits of Employment in Unemployed People. Australian Journal of Psychology 55(2): 95-103.

12. Robert John Mills, Harold G Grasmick, Carolyn Stout Morgan, DeeAnn Wenk (1992) The effects of gender, family satisfaction and economic strain on psychological well-being. Family Relations 41(4): 440-445.

13. Perez JA (2012) Gender Difference in psychological well-being among Filipino College Student Samples. International Journal of Humanities and Social Science 2(13).

14. Roothman B, Kirsten DK, Wissing MP (2003) Gender differences in aspects of psychological well-being. South American Journal of Psychology 33(4): 212-218. 
(C) This work is licensed under Creative DOI:10.19080/PBSIJ.2016.02.555578
Your next submission with Juniper Publishers will reach you the below assets

- Quality Editorial service

- Swift Peer Review

- Reprints availability

- E-prints Service

- Manuscript Podcast for convenient understanding

- Global attainment for your research

- Manuscript accessibility in different formats ( Pdf, E-pub, Full Text, Audio)

- Unceasing customer service

Track the below URL for one-step submission https://juniperpublishers.com/online-submission.php 